\title{
Invented Identity of Thai Monks in Indonesia
}

\author{
Jesada Buaban (เจษฎา บัวบาล) ${ }^{1}$ \\ M.A. in Southeast Asian Studies, Walailak University, \\ Nakhon Si Thammarat, Thailand \\ jesada.tee@gmail.com
}

\begin{abstract}
Thai missionary monks are viewed as passive in the new land on the grounds that though they work abroad, they still serve Thai communities rather than adapt Buddhism to attract the locals. Missionary work in Indonesia is, however, exceptional. This article questions how Thai monks attracted Chinese followers, who have a different background of beliefs. Ethnographic methodology was conducted in Central Java and Sumatra for three months. It found that in order to negotiate with educated lay religious leaders, Thai monks choose to invent an identity of traditional forest monks who are experts in meditation as found in Northeast Thailand. This special figure cannot be found among the laypeople who are immersed in worldly matters like the family and business. Thus, meditation masters from Thailand are often invited to Indonesia not only to provide meditation guidance but also to invent a new identity of Thai Buddhism in Indonesia.
\end{abstract}

\section{Keywords}

identity - missionary - meditation master - Romo/Ramani

1 Currently studying Bahasa Indonesia at Universitas Muhammadiya Makassar, with the support of the Indonesian Ministry of Education and Culture (Darmasiswa Program). 


\section{บทคัดย่อ}

\section{อัตลักษณ์ที่ถูกสร้างใหม่ของพระไทยในอินโดนีเซีย}

พระธรรมทูตไทยมักถูกมองว่าแม้จะทำงานในต่างแดน แต่ก็เน้นพิธีกรรมเพื่อบริการชุมชนไทย มากกว่าจะสามารถใช้หลักธรรมดึงดูดชาวต่างชาติ บทความนี้เสนอว่า งานธรรมทูตในอินโดนีเซีย รอดพ้นจากคำกล่าวหานั้น เพราะสามารถปรับตัวและดึงดูดสมาชิกใหม่ซึ่งเป็นชาวจีนที่มีความเชื่อ หลากหลายได้ ผู้วิจัยใช้วิธีวิจัยทางชาติพันธุ์วรรณนาเก็บข้อมูลที่ชวาและสุมาตราเป็นเวลาสาม เดือน ผลการวิจัยพบว่า พื้นที่ทางศาสนาของอินโดนีเซียถูกขับเคลื่อนโดยฆราวาสผู้ซึ่งมีการศึกษา สูงและเก่งในการเทศน์ ขณะที่พระธรรมทูตไทยไม่เด่นในด้านนั้น จึงเลือกแข่งขันด้วยการสร้าง อัตลักษณ์ใหม่ที่เชื่อมโยงกับพระป่าของไทย โดยการนิมนต์พระป่าไปสอนสมาธิบ่อยครั้ง ซึ่งเป็น ภาพลักษณ์ที่หาไม่ได้ในผู้นำฆราวาสที่คลุกกับการครองเรือน

\section{1 \\ Introduction ${ }^{2}$}

Indonesia is an archipelagic country located in Southeast Asia. It is also the most populous Muslim-majority country. Nevertheless, in order to assimilate its diverse population, the government has adopted a policy emphasizing the five pillars (Pancasila), beginning with the first religious principle: Ketuhanan yang Maha Esa, Belief in the One and Only God (Benyamin 2008, 223). Nevertheless, only six religions, i.e. Islam, Protestantism, Catholicism, Hinduism, Buddhism and Confucianism are recognized by the government (Benyamin $2008,48)$. In the 2010 Indonesian census, $87.18 \%$ of Indonesians identified themselves as Muslim, 6.96\% as Protestant, $2.91 \%$ as Catholic, $1.69 \%$ as Hindu, $0.72 \%$ as Buddhist, $0.05 \%$ as Confucian, $0.13 \%$ as other, and $0.38 \%$ as unstated or not asked (Badan Pusat Satatistik 2010). More specifically, around 1,703,300 are Buddhists (Platzdasch 2014, 4). ${ }^{3}$ There are 3,432 Buddhist temples in Indonesia, including all types of Vihara (tempat ibadah) in every tradition although monks or religious leaders may not be present at some of them (Bimas Buddha 2016).

Theravada Buddhism can be viewed as a new phenomenon in Indonesia because it was officially revived in 1954, after the return of Ashin Jinarakkhita, also known as Tee Boan-an, 1923-2002, an Indonesian-born Chinese who went

2 This paper was adapted from the author's M.A. Thesis entitled "Religious Mobility: The Propagation of Thai Buddhism in Indonesia by Dhammayutta Missionaries" (2017).

3 The percentages of the religious population in Indonesia provided by Platzdasch are different from those provided by the government. Platzdasch wrote that 86 per cent are Muslims, $6 \%$ are Protestants, $3.5 \%$ are Catholics, $1.8 \%$ are Hindu, $1 \%$ are Buddhists, and there are around 0.6 per cent whose religious beliefs are not clearly identified but are assumed to consist of indigenous, syncretic and animist beliefs or Kebatinan (Platzdasch 2014, 4). 
to be ordained as a Theravada monk in Myanmar in 1953. In 1955, about a year after his return to Indonesia, Jinarakkhita established the Fellowship of Laymen and Laywomen Indonesia (Persaudaraan Upasaka Upasika Indonesia: PUUI). PUUI was a Buddhist lay organization. One of the main purposes for establishing PUUI was to encourage lay people to propagate Buddhism alongside monks, as there was a shortage of monks at the time (EdijJuangari 2016, 81). There arose, therefore, the positions of Romo (male teachers) and Ramani (female teachers), who were laypeople approved to play important parts as monks in Buddhist rituals, a role they have continued to play to the present.

A decade later, Jinarakkhita met Charern Suvaddhano (the $19^{\text {th }}$ supreme patriarch of the Thai Sangha) and asked him to send some missionary monks to propagate Buddhism in Indonesia. This invitation was answered when the missionary institute was established in 1966. Thai Dhammayutta Missionaries (TDMs) have been officially sent to many countries to propagate Theravada Buddhism since 1969. All TDM members are initiated, trained, and supported by the Institute of Dhammaduta Going Abroad (TIDGA), which was founded in 1966 at Wat Bowornives Vihara, Bangkok, with the support of the Thai government through the Department of Religious Affairs, Ministry of Education. This institute moved to Wat Phra Sri Mahathat Bang Khen in 2016. The first group of TDM sent to Indonesia in 1969 consisted of four monks, with Bhante Win $^{4}$ or Phra Maha Win Vijjano as the leader. Nevertheless, this first mission was not initiated without native patrons, as they were invited and supported by Jinarakkhita, the leader of Indonesian Buddhists at that time. In 2014, 19 TDM and 37 TDM assistants were working in Indonesia. A total of 22 temples have been built in several regions. Buddha Metta Arama in Central Jakarta and Vipassana Graha in Bandung are main temples functioning as TDM administrative centers.

It should be added that Dhammayutta in Thailand is very diverse. They can be roughly separated into two groups: Dhammayutta in Bangkok, who prefer to study the scriptures and perform rituals to the monarchy, and Dhammayutta in northeast Thailand, where many forest temples have been built and strict meditation is promoted. However, this category is flexible, because some Dhammayutta monks in the northeast as well as other parts of Thailand may also like to study. According to my fieldwork in 2015, more than 90\% of TDM members were from northeast Thailand. Of course, most of them also prefer to wmeditate rather than study the religious texts and discuss the content of Buddhism.

4 Bhante is a Pali word which is generally used by Indonesian Buddhists to call Theravada monks regardless of their country of origin. It can be translated as "Venerable." This research project also uses this term in the same way as used by my informants. 
In fact, Thai monks should be considered as assistants to Indonesian monks and Romo/Ramani in teaching Buddhism. This was true in the very beginning when TDM members had to stay in Indonesian temples or Chinese shrines (Klenteng). However, as the number of imported monastic members increased and their own temples were built, they became more independent and established their own organizations (Yayasan). However, as Indonesia is officially a secular state, no religious organization receives funding from the government, and Thai monks and other native Indonesian organizations must struggle to attract followers and donors. In order to maintain one's own organization, various new methods are created to respond to people's needs, which is typical of religions in all historical periods. This paper, therefore, questions how Thai monks have generated a new identity and methods to attract new followers given that they must compete with native Romo and Ramani. Ethnographic fieldwork was conducted in Jakarta for two months in 2015 and one month in Medan, North Sumatra in 2016.

I focused on these two islands because most Thai monks have also settled in these places. It should be mentioned that among my informants, there were three main leaders who can speak Bahasa Indonesia very well, namely Bhante Wongsin, Bhante Kamsai, and Bhante Kanit. Other monks (whose Bahasa skills are not good) have preferred to stay with these three leaders, and interestingly three of them have always remained in Java. In the case of Medan (Sumatra), a new temple, Labhiko Buddhist Center, has been built and Bhante Wongsin visits regularly. Large photos and relics of Thai forest masters constitute the temple's main identity. In fact, temples on other islands are not the main center for propagating Thai Buddhism. Many of them are empty, without any monks, for example Vihara Happy Family in Palu (Sulawesi). Simply put, in 2015, the forest monks were invited to Java and Sumatra only.

As a Buddhist monk, I stayed in Thai temples and participated in various activities arranged by both Thai monks and native Indonesian organizations. All data were analyzed through the concept of commodification, in which religion is perceived as an invented product to serve new needs.

This paper is organized into six parts. (1) Introduction: provides background on problems and justification, research questions, as well as methodology. (2) Conceptual Framework: the concept of commodification was adopted in this paper to demonstrate how Thai Buddhism in Indonesia is a process of commercializing the forest monks. (3) Romo VS Thai Monks: elucidates some relationships between them as well as their struggles to occupy the religious sphere. (4) Invitation of the Forest Monks to Indonesia: explains the very effective strategy adopted by Thai monks to attract Indonesian patrons. In this part, the forest monks are viewed as valuable products. Moreover, in order to increase the value of that holy product, the storytelling about the Arahanta, the 
transference of Arahanta status in the Dhammayutta school, and Arahantas' relics are reinterpreted as religious legitimacy and intensity of identity of Thai monks in Indonesia. (5) Dhamma Tours to Thailand: reveals the monks' way to educate Indonesian followers in Thai Buddhism. Finally, (6) Conclusion: restates the main argument of this paper.

\section{$2 \quad$ Conceptual Framework}

According to Marxist theory, commodification is the process of making commodities, a process in which non-saleable things are made saleable (Kosoy and Corbera 2010, 1229). Not only products but services, lifestyles and even ideas can also be commoditized. For example, the techniques for proper breast feeding were previously passed down from mother to daughter, but now there is a market for lactation consultants. In consequence, one of the most intimate human functions has become commoditized (Rushkoff 2005). The traditional forest monk from Thailand is certainly not a religious material that consumers can everlastingly possess at home, but it is imported to Indonesia by TDM members as a mobile spiritual service. The forest masters become more accessible to Chinese in the city, a phenomenon which the forest masters may not consider as commoditization but as religious propagation instead. However, it cannot be denied that TDM and the forest masters make large sums from the trips. Many dozens of clerical materials (Sanghadana) provided by Thai temples are bought and offered to those masters in hopes of receiving great merit and business success in return.

However, according to Mara Einstein, the market and religion are not at war against each other. Instead, religion adopts market logic. It has built its moral and spiritual empires based on market principles and models (Einstein 2007, 12-14). The market, in turn, may adopt religious faith to support its economic profits. Simply put, the commodification practiced by Thai monks should theoretically not be perceived as the degeneration of religion but rather as another process of religious adaptation in a different atmosphere. Scholars have treated secularization as part of the increasing complexity and diversity of modern industrial society. Moreover, it is the later stages of the evolutionary process that allow individuals to make choices about which worldview they will accept (Roberts and Yamane 2012, 328-329). In order to survive in the modern era, many religions thus reinvent themselves to compete for attention and affiliation from consumers in the spiritual marketplace (Pattana 2010, 564). 
TDM members in Indonesia are undoubtedly following this method. The low price of airfare, easier transportation, and modern communication technologies all make it easier for the TDMs to invite forest masters from Thailand and advertise their Dhamma Talk activities among the Indonesian Chinese, essentially facilitating the process of commodification. This corresponds to Ward's suggestion that religious commodification is nothing new; what is new is the technology that can facilitate a global systematization of this commodification, so that all religious traditions can be branded, and their worldview can be globally consumed (Ward 2006, 185). Employing this particular concept to describe Thai missionary work does not, therefore, imply that Buddhism is in crisis but that its transnational brand helps to attract new patrons, and has eventually formed a new identity of Thai Buddhism in Indonesia.

\section{$3 \quad$ Romo VS Thai Monks}

Conflicts between Indonesian Buddhist scholars (Romo/Ramani) and TDM members are regularly overlooked because both groups are viewed as having helped each other to propagate Buddhism in Indonesia. However, this paper proposes that there are some tensions between them. Historically, Romo and Ramani evolved from the Fellowship of Laymen and Laywomen Indonesia (PUUI) that was established in 1955 by Jinarakkhita a year after his return from Burma. PUUI was a Buddhist lay organization in which both Theravada and Mahayana monks were included. Nowadays, PUU has evolved to be the Association of Buddhayana Indonesia (Majelis Buddhayana Indonesia: MBI). One of the main purposes in establishing the PUUI was indeed to encourage lay people to propagate Buddhism as monks, due to the lack of monastic members (Edij Juangari 2016, 81). Romo and Ramani have been approved to play the monks' roles in Buddhist rituals until today.

A question that can be raised is why the Thai monks in Indonesia seem to be promoting traditional forest masters rather than their capacity for giving rational Dhamma talks? That is because, according to the interviews with Ardi, Mariam, and Wawan in 2015, Romo and Ramani are well qualified in Buddhist Studies and their sermons are therefore equal to or better than those given by monks. They were trained in both religious knowledge and ritual performance. They often play the monks' role wherever monks cannot be found. Notably, not everyone can become a Romo or Ramani. In fact, she/he must be recruited by M B. Various skills are also required. A certificate and a yellow scarf will be given to a candidate as symbols of being Romo or Ramani. Actually, their 
capacity in Dhamma Talks is recognizably better than TDM because some of them are also qualified in Buddhist scriptures and hold university degrees. Consequently, to the TDM, to depict the intensive meditation practice and very strict monastic codes observed by the traditional forest masters is more effective in attracting followers interested in meditation.

Most Romo and Ramani are university-educated Chinese. Some of them have м вA degrees from the West. This means that they can perform rituals on Sunday without abandoning their business. According to interviews with Romo Hariono and Romo Hendrik in 2015, many of them graduated from Nalanda Buddhist colleges (Sekolah Tinggi Agama Buddha) in Jakarta. Moreover, Dhamma books available in Indonesia are mostly translated from English by two large Buddhist publishers, namely Ehipassiko ${ }^{5}$ and Dhammacitta. ${ }^{6}$ Undeniably, Romo and Ramani (and other Indonesian Buddhists) are influenced by those English translated books. This claim can be clearly seen in their sermons. Their talks are always based on the scriptures such as "according to the Buddha's teaching in Samyutta Nikaya, No. 10" while TDM members normally refer to traditional forest masters such as "in the bibliography of Luangpu Mun narrated by Luang Ta Maha Bua." However, though some Thai monks are welleducated in scriptures, referring to a forest monk's teaching is more attractive in Indonesia, where the monks have chosen to create a new identity related to the forest monks.

My field-observation in Vipassana Graha and an interview with Ibu Rossana in 2015 found that a sermon given by Roma/Ramani is more interesting than a sermon by Thai monks, because if a Talk Show featuring Romo/Ramani or other lay scholars is organized in some place nearby, more people choose to attend it than a monk's sermon in a temple. In terms of hierarchy, though the Romo's and Ramani's capacity in giving a sermon is generally better than that of TDM members, as lay devotees, they also pay respect to the monks in both action and speech. Interestingly, if a traditional forest master is invited from Thailand, he is quite successful in attracting Indonesian Buddhists, probably because the status of a celibate monk who practices in the forest temple is more suitable

5 Translated books published by Ehipassiko include, for example, Don't Worry Be Happy (by Ajahn Brahm), Tipitaka Tematik (The Essence of Tipitaka by Bhikkhu Bodhi), Encyclopedia of Tipitaka (by G.P.Malalasekera) and so forth. See more details about the Ehipassiko Foundation at http://ehipassiko.net/ (Accessed May 3, 2017).

6 Translated books published by Dhammacitta include, for example, Bagaimana Memiliki Agama (How to Choose a Religion? by K. Sri. Dhammananda), Khotbah-Khotbah Berkelompok Sang Buddha Majjhima Nikaya (The Middle Length Discourses of the Buddha, compiled by Bhikkhu Bodhi) and so on. See more details about Dhammacitta Publisher at https:// dhammacitta.org/ (Accessed May 3, 2017). 
for guiding meditation than lay Romo and Ramani who are still involved with family members. In addition, Romo and Ramani also participate in rituals when they are arranged and led by forest meditation masters.

Wedding ceremony (Acara Pernikahan) is another example that clearly demonstrates the struggle between Romo/Ramani and Thai monks to occupy religious space. Indonesian Buddhists, especially the Chinese patrons, tend to hold their wedding in the temple. This trend may have been adapted from Christian tradition. Interestingly, the ceremony is commonly not performed by a monk but by Romo or Ramani instead, for two reasons. First, Romo and Ramani, according to Bhante Wongsin, have been playing this role since before the arrival of Thai missionaries, and therefore, it has become his/her duty. Second, TDM members, as Theravada monks, are not suitable for a worldly ceremony related to household matters. This second reason was given by Romo Hendrik in March 2015. However, some monks in the Mahayana tradition do, in fact, conduct this ceremony.

In terms of the ceremony itself, the wedding couple begins by lighting a pair of red candles. Interestingly, each step in the process must be clearly explained by a Romo, for example, "red candles symbolize loving-kindness, which means the couple must cultivate loving-kindness toward all beings." Then, the Romo starts to chant a short Sutta in Pali and continues with the Five Precepts. Commonly, the Five Precepts are first chanted by monks and repeated by lay people in every ceremony. But in this ceremony, the monks' role has been replaced by the Romo. Of course, many seats are also provided for attendants.

Similarly, to Christian tradition, the couple must introduce themselves and take a vow in front of the Buddha that they will love and take care of each another. The same series of questions is also asked by the Romo/Ramani as would be asked by a Christian priest. Then, the wedding couple are covered with a big yellow cloth. The Romo gives a ten-minute sermon and concludes by filling out the marriage certificate. That certificate is issued in the name of the monastery, and therefore it is not legally valid. Nevertheless, it cannot be denied that the ceremony helps increase the identity of being Buddhists in a country where Muslims are the majority.

At some wedding of devotees who are very familiar with the temples, Thai monks are also invited to chant the Sutta. However, the entire ceremony is still run by a Romo or Ramani. It clearly reveals that various spheres of Indonesian Buddhism are occupied by lay leaders. This paper in fact focuses on religious rituals only. There are also many other spheres which Thai monks cannot access such as the administrative committee of a foundation (Yayasan), which a Thai monk, as a foreigner, cannot lead. As a result, though they have worked in Indonesia for many years, by carrying an Official Passport, they are considered as Thai bureaucrats and cannot acquire Indonesian citizenship. The only 
exception is the case of Bhante Kanit. He traveled on an ordinary passport, and after living in Indonesia more than ten years, he was given citizenship. As a result, among all TDM members in Indonesia, based on the law, only Kanit is the leader of his own foundation, while other TDM abbots do not have the legal power to serve as administrative committee leaders. Consequently, it is not odd to find that TDM members must struggle to occupy certain spheres and roles. Inviting Thai meditation masters to Indonesia, according to this paper, is one of many strategies adopted by TDM.

\section{Invitation of the Forest Monks to Indonesia}

Traditional forest monks (TFM) in Thailand are often invited by TDM members to give sermons in Indonesia on the grounds that many TDM members today are from forest monasteries. By so doing, the authentic lineage of Dhammayutta forest monks, who are associated with meditation practice, can be obviously symbolized, which ultimately attracts Chinese patrons to support the TDM's mission. In this section, the invitation of TFMS is conceptualized through the concept of commodification on the grounds that this phenomenon can be considered as a process of commercialization of TFMs. In addition, it is aimed not only for financial gain but also for the intensification of Dhammayutta identity of TDM members. More interestingly, this phenomenon finally helps TDM, who have already moved to Indonesia, to create a trans-local religious space that is not separate from Thailand.

In Thai people's perspective, life as a Dhammayutta forest monk is suitable for those who prefer to observe the stricter monastic codes and to immerse themselves in intensive meditation rather to be primarily involved in the study of religious scriptures (Tipitaka) and the performance of rituals for villagers. The forest tradition is, as a result, broadly recognized as the direct form of practice for the cessation of suffering according to the Buddhist tenets. Notably, many TDM members are originally from the forest tradition. According to my field-observation, many of them still read Thai Dhamma books, review Thai chanting, and listen to Thai Dhamma talks (mostly by Luang Ta Maha Bua) in their personal rooms. This is similar to the case study of Siamese Buddhists on the Thai-Malaysian border by Irving Johnson (2013). There, Thai Buddhists in Kelantan are linked to Thailand through cross-border travel, learning Thai language and performing Thai customs in Thai temples, watching Thai TV, and showing loyalty to the Thai monarchy while not abandoning the local Sultan in Malaysia. For Thai monks in Indonesia, it is therefore not surprising to find that they are attempting to maintain or at least express their origins 
by commercializing this lineage. Luangpu Liem is a good example of this phenomenon.

\subsection{Forest Monks as Valuable Products}

Luangpu Liem Thitadhammo, or Chaokun Phra Raj Bhavanavikrom, Luangpu Chah's pupil, ${ }^{7}$ was ordained in 1960 in Sisaket Province and has lived with Luangpu Chah from 1969 onward. After his fifth day there, his robes and other clerical materials were offered to him by Luangpu Chah himself. This symbolizes the close relationship between them. Luangpu Liem practiced meditation under Luangpu Chah's guidance and finally became the next abbot of the temple in 1994, two years after the passing of Luangpu Chah.

Regarding his trip to Indonesia, he was invited by Bhante Kamsai to visit on March 20-25, 2015. Dhamma Talks were arranged in many places, namely Jetiya Buddhametta Khemapatto, Jakarta Barat on the $20^{\text {th }}$, Vihara Pluit Dharma Sukkha, Jakarta Utara on the $21^{\text {st }}$, Buddhametta Arama, Jakarta Pusat on the $22^{\text {nd }}$ and Perumahan Taman Sunter Agung Bisma Block B, Jakarta Utara on the $23^{\text {rd }}-24^{\text {th }}$. In Indonesia, he was accompanied by a group of monks from Wat Nongpahpong. One of them was Luangpu Chandii, another famous meditation master in the traditional forest lineage, who acted as an assistant in dealing with the audience members' questions. My fieldwork observation was conducted on March 20, 2015, at Buddhametta Arama, where approximately 300 people attended the ceremony.

The ceremony began at 05.15 p.m. with a short period of chanting and observing the Five Precepts, followed by Luangpu's talk. He talked about the facts of life; how we are subject to birth, aging, and death as well as all lamentations. In order to escape them, one must concentrate and develop his wisdom through meditation until he fully realizes that all things are merely the aggregation of four elements: earth, water, wind and fire. The body, in the example he used, should be comprehended in that way. Suffering will not occur if one perceives his body as a combination of these four impermanent elements. This

7 Luangpu Chah or Chao Kun Phra Bodhinyana Thera (1918-1992) was a very famous mediation master from Ubon Rachathani province who had practiced with Ajahn Mun. He had many Western followers including Sumedho (Robert Karr Jackman in the UK), Brahmavamso (Peter Betts, now living in Australia) and others (Details about biography of Ajahn Chah, http://www.ajahnchah.org/book/About_Ajahn_Chah.php. Accessed September 15, 2017).

Notably, Luangpu Chah belonged to the Mahanikaya. It is said that he was also interested in converting to Dhammayutta but was not allowed by Luangpu Mun, for the reason that "practicing the Dhamma is not limited by any school, you must maintain in Mahanikaya and become an exemplary. Otherwise people would wrongly believe that enlightenment is available only to Dhammayutta monks" (Dhamma talk given by Luangta Maha Bua, September 27, 2002. Accessed February 10, 2016 from website http://pantip.com/topic/30826715). 
Dhamma talk lasted around one hour with half the time being a Bahasa Indonesia translation given by Kamsai. The translation was different from the original talk, however. Kamsai, whose background is related both to the forest tradition and to Abhidhamma studies, only caught the essence of Luangpu's talk and translated it into Bahasa Indonesia using his own style, words and examples. The audience seemed very bored by Luangpu's sermon due to the inaccessible Thai language. They were, however, satisfied with Kamsai's translation.

Then, the ceremony moved to the offering of material objects and money to the monks. Each set of materials cost $\$ 22$ (IDR 300,000) and a set of yellow robes cost $\$ 37$ (IDR 500,000).

These materials were notably provided for sale by Buddha Metta temple and, interestingly, the entire supply of 100 sets sold out. After this section, Luangpu and the other monks chanted a blessing in Pali, and then Kamsai, at Luangpu's invitation, sprinkled holy water on all the participants. The activity concluded with a dinner prepared outside the hall by the Chinese devotees. The whole ceremony took approximately two hours.

I was told by Kusuma, an Indonesian Chinese monk, who stays in the Buddha Metta Arama, that many people decided to participate in this ceremony because they were convinced that Luangpu Liem and Luangpu Chandii were Arahantas, or 'noble ones.' They also believed that making offerings to the noble ones would produce much merit, which would help increase their business profits.

TDM members in Indonesia and most Dhammayutta monks in Thailand perceive selling amulets as improper behavior prohibited by the monastic codes. The invitation of TFMs to Indonesia is, in many TD M's opinion, not considered commerce but as a way of helping people to reach Nirvana through sermons. However, inviting famous masters helps to reaffirm the TDM identity as directly linked to the Thai forest tradition. These invitations also reaffirm TDM's religious authenticity not through the study of original texts but through the right meditation practice that ultimately leads to the state of Arahantas. It should be recognized that TDM members in Indonesia have to immerse themselves in secular and social welfare activities. Most of these activities were initiated by the Chinese followers. Thus, their sacred status and reputation for strict practice has inevitably decreased. Therefore, inviting famous Arahantas from Thailand can help to present a positive image of Dhammayutta, which ultimately helps to intensify their authentic identity. Dhammayutta is a new monastic order, which attempted to respond to a modernizing Thai society in the nineteenth century. It is also claimed to be an authentic tradition whose practice is based on the Pali scriptures. Claiming to be authentic is, according to Appadurai, a prominent value of modernity (Appadurai 1986, 45). 
For the Chinese followers, the decision to participate in Thai Dhammayutta Dhamma talks in order to accumulate merit as a crucial tool for supporting their business enterprises is partly true. Moreover, it seemed that many of the Chinese participants were also motivated by a direct preference for listening to the Dhamma talks in order to develop their meditation practices. The many questions they raised can be cited as evidence of this. ${ }^{8}$ These multipurposeevents fulfilled multiple needs of the Chinese consumers. This corresponds to Berger's suggestion that religious commodification offers one of the most accessible ways for individuals to consume (Berger 2008, 15). This method is notably used by TDM members to tell their story and to re-evaluate their history (Cole 2007, 956). In addition, the figure of TFMs from Thailand is a symbol, which contains powerful religious messages and generates a sense of membership and identity both for monks and for their lay followers (Pattana 2010, 567).

\subsection{Transference of Arahanta Status in Dhammayutta School}

The above section has mentioned the process of commodification performed by TDM in Indonesia. It is also important to discuss how these traditional forest masters gain and maintain their Arahanta status in Thailand. Jirasak, who had worked as a missionary in Korea for four years, hypothesized that Arahantaship in the Dhammayutta lineage is transferred from the master to his close pupils. In general, the forest tradition is perceived by Thai people as a direct way of practice for reaching enlightenment (Nirvana), and most of the traditional forest masters are, therefore, assumed to be Arahanta. There is traditionally a pupil who serves him nearby, participates in every activity, follows him to practice in the forest, and listens to his Dhamma talks on every occasion, etc.

This particular follower is moreover greatly trusted by his master. This pupil is sometimes called "Luangpu's right-hand," and he also works as the abbot's assistant. Most interestingly, when the Luangpu dies, his close pupil will automatically become the next abbot and also be believed to be an Arahanta. This is because if he were not believed to be an Arahanta, people would also have to deny the Arahanta status of the former teacher. If the former teacher could not teach the present abbot to become an Arahanta, he himself therefore must not be an Arahanta. Becoming an Arahanta is important in order to maintain the forest tradition. Luangpu Liem, Luangpu Chah's pupil, is an obvious example

8 Dhamma Talks of the traditional forest masters are readily available on YouTube Channels. These talks are also followed by both TDM members and Indonesian Chinese who can speak Thai such as Ibu Honey and Ibu Christin. One of the famous teachers, who is also often invited to Indonesia, is Luangpu Inthawai Santussako, Wat Pa Nakamnoi, Udon Thani. Those devotees can follow his teachings on YouTube-Live every morning. 
of this claim. However, Jirasak's hypothesis does not necessarily mean that anyone who practices near a famous meditation master will naturally become another Arahanta. Rather, he suggests that such positions are reserved only for certain people. The desirable behaviors, the specific style of Dhamma talk, the rank of abbot's assistant, and sometimes even the Luangpu's confirmation are needed. ${ }^{9}$

Another important example is found in the biography of Luangpu Liem Thitadhammo. His legitimacy as a person thought to be an Arahanta and as the next abbot after Luangpu Chah are strongly related to the clerical materials which he inherited from Luangpu Chah himself. Interestingly, this particular tradition parallels what happened in Zen (Chan) history when the master would transmit his highest leader position to his pupil. The robe or bowl, as in Hui-Neng's biography, for instance, was also conveyed as symbolic of a master's inheritance (Cleary 1998, $5^{-15}$ ). Moreover, such inheritance traditions are commonly found in religious sects that emphasize the oral tradition. Zen, Vajrayana and Dhammayutta forest monks all share this tradition (Tagchungdarpa 2014, 10-11). In all three traditions, it is believed that only reading the religious texts and engaging in the practices alone without the master's guidance are unlikely to achieve success. A master who orally transmits the specific teaching to a specific pupil is, therefore, seen as essential. In this regard, the Dhammayutta forest tradition should be recognized as not only orthodox in theory, but also esoteric in practice.

\subsection{Arahantas' Relics, Religious Legitimacy and Intensity of Identity}

In terms of the affirmation of Dhammayutta identity, the role of the Buddha's and the Arahantas' relics should be investigated further. Vipassana Graha is the main office of TDM. It is located in Lembang, Bandung, and was designed as a tourist attraction. A huge pagoda named Pancamahabala was built to house the Buddha's and various Arahantas' relics on the second floor, whereas the first floor is used as an Uposatha (the hall used for monks' important rituals, especially ordination). Apart from the Buddha's relic, more than fifty sets of

9 The tradition of the master's confirmation (พยากรณ์) became popular in the time of Luangta Maha Bua. He was Luangpu Mun's follower and was later believed to be an Arahanta. In his Dhamma talks, many traditional forest masters were explicitly referred to as Arahanta. Interestingly enough, the tradition of confirmation by the master is overlooked by Tambiah (1984) and Kamala (1997), who proposed that Arahanta or charismatic monks are legitimized by their miraculous potential. Luangpu Jiea Cundo, whose speech was rude, was not believed as being an Arahanta. But when Ajahn Mun announced that Jiea was an Arahanta, all forest monks were convinced and they included him as a respectful master in the forest tradition (Dharma-Gateway 2013). 
Arahantas' relics from the Thai forest tradition are also on display. The specific names of the Arahantas such as Luangpu Mun, Luangpu Dul, Luangpu Jia, Luangpu Sim, and so forth appear on each set. These objects are traditionally intended for worship. At the same time, they symbolize the TDM's identity with the forest ancestors who had passed while leaving something behind, an Arahantas' crystal bones.

John Strong (2004) has discussed in his book Relics of the Buddha the relationship between the Buddha's relics and the Dhamma (His teaching). Relics, the footprint for example, represent not only the Buddha's coming into but also his going away from this world. This is because the relic cannot be found without the Buddha's arising and is always used as a commemorative object after his passing. This phenomenon can also be expressed in terms of the fundamental Buddhist principle of arising and cessation (Strong 2004, 86). In the Theravada tradition, possession of the Buddha's relics can, however, bring legitimacy, as in the case of Buddhagosa in the $5^{\text {th }}$ century who owned a relic and used it as justification for building a proper monastery. In addition, Richard Gombrich (1971) has stated that there is only one temple in Sri Lanka that does not claim to possess a relic (Strong 2004, xiv). In terms of political power, not only did possession of a relic or a state elephant legitimize rule but it also acted as an auspicious guarantor of order, prosperity and fertility (Strong 2004, 184). And at the very least, the Buddha's relic can at least represent the historical Buddha who really existed at some period. This last sense seems very important to ensure Buddhists of their human religious leader.

I generally agree with Strong's concepts about the Buddha's relics. However, there is more that can be said about the TDM's reasons for exhibiting the traditional forest masters' relics. These Arahantas' relics are physical evidence confirming their existence in the past, not as ordinary people but as Noble Ones, who had perfectly purified their minds of all sinful matters. This mental quality is very difficult to evaluate, hence the expectation of a physical miracle, such as the crystal bones (relics) that can signify this purification. In general, these Arahantas' relics are used to recall the passed away teacher who tirelessly exerted himself to meditate and finally reached the Arahanta's status. This acknowledgment should also motivate the new meditators. However, these relics are traditionally not allowed to be scientifically verified. As mentioned earlier, the traditional forest Dhammayuttas prefer to immerse themselves in intensive meditation rather than learn religious scriptures. As a consequence, they are not scholarly experts in explaining the Dhamma. The evidence that can, in my opinion, fit their style of life and thought is the crystal relics, which are broadly recognized as the result of the right way of practice. I propose that TDM members in Indonesia employ these relics not only to implicitly narrate 
their own story about Thailand and the Dhammayutta tradition but also to legitimize themselves as being part of the Noble Ones' lineage.

Interestingly, not only are TFMs invited to Indonesia, but Indonesian people also visit these monks in Thailand through a Dhamma tour program. TDM members frequently offer this pilgrimage trip to Thailand, mostly to Bangkok and the Northeast. Commonly, the trips are arranged by Rangsan quarterly and are led by Kamsai once a year. This Dhamma tour is attended by around $15^{-30}$ people. Also, they sometimes go to India. On these trips, the Indonesian Chinese have a chance to learn about the Dhammayutta tradition. They are trained to meditate, to offer some food in the monks' alms bowls (Pindapata), and to treat monks with proper (Thai) manners. It should be kept in mind that Thailand, in the perception of both Indonesian Chinese and TDM members, is the hub of Theravada Buddhism. As a result, having the chance to experience the lifestyle of these masters in their own monasteries is like consuming the authentic Buddhist way of life. In fact, many Indonesian Chinese have visited Thailand and especially the forest monasteries. Many of them go to Thailand in the company of Prasan, Wongsin and other TDM members as well as many Indonesian monks from SAG IN (Sangha Agung Indonesia) who ordained with Luang Phor Art (Chaokhun Prasadsarakun), the leader of clerical administration in Buriram.

It needs to be mentioned that the traditional forest masters in Thailand do not always wander from forest to forest as we previously understood. Instead, they settle in temples in some quiet areas and name the forest monasteries. Meditation masters who play an abbot's role may rarely travel to the forest; nevertheless, they have to guide both their monastic and lay students. According to James Taylor $(1993,86)$, this change was brought about by the nation's policy to centralize monks as a means of control and of assigning them to serve state policy. Rapid and affordable transportation allows TDM members to invite their masters from the forest temples to intensify their Dhammayutta identity, to tell their origin, and to attract Chinese patrons. Similarly, Indonesian devotees can consume the 'real' lifestyle by visiting those monks in Thailand through participating in Dhamma tours. Of course, this kind of lifestyle cannot be guided by lay Romo and Ramani. This case clearly shows the continued connectedness of TDM members with their forest monasteries though they have moved overseas to work. Not only is the old network in Thailand maintained, but those masters help TDM to create and maintain a network with Indonesian Chinese as well. 
Dhamma tours can also be viewed as a chance to indirectly educate Chinese devotees about the strict Dhammayutta discipline. The Chinese have opportunities to visit many forest temples, practice meditation under the guidance of famous masters, and learn how to interact with monks in proper ways. The perception of authenticity has been recognized as an international consideration and a driving force that motivates tourists to travel to distant places and different times (Frochot and Batat 2013, 132). Consequently, the above-mentioned strategies will be characterized by commodification, which results not only in financial gain but also in an intensification of TDM's identity. According to Macdonald (1997), cultural commodification can be used by the locals as an instrument to affirm their identity, tell their own story, and establish the significance of local experiences.

\section{Conclusion}

A question was raised in this paper as to why the TDM in Indonesia seem to promote the tradition of forest monks rather than the capacity to give Dhamma talks in accordance with Dhammayutta orthodoxy. It finds that in Indonesia, there are lay Buddhist scholars, Romo (male) and Ramani (female), who are well qualified in Buddhist studies. These people can functionally preach as well as or better than monks, because they are trained in both religious knowledge and ritual performance. Consequently, depicting the intensive meditation practice and very strict monastic codes observed by the forest tradition is more effective. In addition, Thai monks should not be viewed as entirely uneducated in religious scriptures, because many have also graduated with a Master's Degree from Mahamakut Buddhist University. However, in the process of commoditization, the story of Arahanta, or references to Noble Ones, whose mind was purified through intensive meditation practice, and the building of pagodas to represent the relics, Arahantas' bones, are important tools that are totally absent in the characteristics of Romo and Ramani.

Invitations of traditional forest monks to Indonesia can be seen as the process of reinventing the identity of the TDM who have been working in Indonesia. Though some TDM members are not originally from forest temples, claiming to be familiar with the forest meditation masters and accepting invitations to teach in Indonesia help to legitimize their image as meditative monks, which cannot be attributed to Romo and Ramani. This clearly shows that in order to compete with other religious leaders, Thai monks have had to adopt certain strategies to attract patrons, as we have seen in this paper. The forest monks are commercialized not only to solicit financial donations but also to intensify their meditative identity. To sum up, religious identity can be 
reinvented when Thai monks negotiate with the lay Indonesian religious leaders. However, the identity of traditional forest masters as well as Dhammayutta monks in Thailand should also be studied and focused on from many other dimensions in order to identify more dynamics. We should not be satisfied with the conclusions of Taylor's book (1993), which mainly elucidates the relationship between monks and the Thai state.

\section{References}

Appadurai, Arjun. 1986. "Introduction: Commodities and the Politics of Value." in The Social Life of Things: Commodities in Cultural Perspective, edited by Arjun Appadurai, 3-63. Cambridge: Cambridge University Press.

Badan Pusat Statistik [Center of Statistics]. 2010. Penduduk menurut wilayah dan agamayang dianut Indonesia [Population by Region and Religion in Indonesia]. Accessed May 20, 2016. http://sp2010.bps.go.id/index.php/site/tabel?tid=321\&wid=0.

Benyamin, Fleming Intan. 2008. Public Religion and the Pancasila-based State of Indonesia: An Ethical and Sociological Analysis. NY: Peter Lang.

Berger, Peter. 2008. "Religious America, Secular Europe?" In Religious America, Secular Europe?: A Theme and Variations, edited by Peter Berger, Grace Davie, and Effie Fokas, 9-21. Aldershot, England: Ashgate.

Bimas Buddha [Office of Guidance for Buddhists in Indonesia]. 2016. Portal Sistem Informasi Data Bimas Buddha [Gateway System of Information about the Office of Guidance for Buddhists]. Accessed May 21, 2016. http://bimasbuddha.kemenag.go.id/ portal_data/.

Cleary, Thomas. 1998. The Sutra of Hui-neng, Grand Master of Zen: with Hui-Neng's Commentary on the Diamond Sutra. London: Shambhala Publications.

Cole, Stroma. 2007. "Beyond Authenticity and Commodification." Annals of Tourism Research 34, no.4: 943-96o. http://dx.doi.org/10.1016/j.annals.2007.05.004.

Edij, Juangari. 2016. Menabur benih Dharma di Nusantara: Riwayat singkat Y.A.MNS Ashinjinarakkhita [Sow the Seed of Dharma in the Nation: A Short Biography of Ven. Ashinjinarakkhita]. Jakarta, Indonesia: Karaniya.

Einstein, Mara. 2007. Brands of Faith:Marketing Religion in a Commercial Age. London: Routledge.

Frochot, Isabelle, and Wided Batat. 2013. Marketing and Designing the Tourist Experience. Oxford: Good Fellow Publishers.

Gombrich, Richard. 1971. Precept and Practice: Traditional Buddhism in the Rural Highlands of Ceylon. NY: Oxford University Press.

Johnson, Irving Chan. 2013. The Buddha on Mecca's Verandah: Encounters, Mobilities, and Histories along the Malaysian-Thai Border. Washington: University of Washington Press. 
Kosoy, Nicolas, and Esteve Corbera. 2010. "Payments for Ecosystem Services as Commodity Fetishism.” Ecological economics 69, no. 6: 1228-1236. http://dx.doi.org/ 10.1016/j.ecolecon.2009.11.002.

MacDonald, Sharon. 1997. "A People's Story: Heritage, Identity and Authenticity." In Touring Cultures: Transformations of Travel and Theory, edited by Rojek Chris and John Urry, 155-176. London: Routledge.

Pattana, Kitiarsa. 2010. “Toward a Sociology of Religious Commodification." In The New Blackwell Companion to the Sociology of Religion, edited by Turner Bryan, $563^{-583}$. Oxford:John Wiley \& Sons.

Platzdasch, Bernhard, ed. 2014. Religious Diversity in Muslim-majority States in Southeast Asia: Area of Toleration and Conflict. Singapore: ISEAS.

Roberts, Keith, and David Yamane. 2012. Religion in Sociological Perspective. London, England: SAGE Publications.

Rushkoff, Douglas. 2005. Commodified vs. Commoditized. Accessed May 23, 2017. http:// www.rushkoff.com/blog/2005/9/4/commodifiedvscommoditized.html.

Strong, John. 2004. Relics of the Buddha. Princeton: Princeton University Press.

Tagchungdarpa, Amy. 2014. The Social Life of Tibetan Biography: Textuality, Community, and Authority in the Lineage of Tokden Shakya Shri. Maryland: Lexington Books.

Taylor, James. 1993. Forest Monks and the Nation-state: An Anthropological and Historical Study in Northeastern Thailand. Singapore: Institute of Southeast Asian Studies (ISEAS).

Ward, Graham. 2006. "The Future of Religion." Journal of the American Academy of Religion 74, no.1: 179-86. http://dx.doi.org/10.1093/jaarel/lfjo24. 